\title{
HUBUNGAN TINGKAT KEMANDIRIAN DAN GANGGUAN KOGNITIF PADA LANSIA
}

\author{
Resti Rahmadika Akbar ${ }^{1)}$, Dian Ayu Hamama Pitra, ${ }^{1)}$ Mutiara Anissa, ${ }^{1)}$ Debie Anggraini' \\ ${ }^{1}$ Fakultas Kedokteran, Universitas Baiturrahmah, Jalan By Pass Km15 Aia Pacah, Kota Padang \\ email: restirahmadikaakbar@gmail.com
}

\section{Submitted : 06-05-2020, Reviewer:12-05-2020, Accepted: 12-05-2020}

\begin{abstract}
Abstrak
Peningkatan jumlah penduduk lansia menjadi tantangan sendiri. Pemenuhan fasilitas, sistem serta peran dari pemerintah dan masyarakat dengan tujuan meningkatkan kualitas hidup lansia.. Salah satu aspek yang terkait dengan proses penuaan adalah penurunan fungsi yang mencakup psikologis, sosiologis dan biologis. Salah satu perubahanan yaitu penurunan fungsi kognitif. Penuruan fungsi pada lansia juga menjadi faktor yang mempengaruhi tingkat kemandirian dari lansia. Tujuan penelitian ini adalah untuk menilai hubungan tingkat kemandirian dan gangguan kognitif pada lansia. Penelitian ini menggunakan desain cross-sectional dengan teknik pengumpulan sampel convenience-sampling. Sampel penelitian ini merupakan pasien prolanis. Pengumpulan data menggunakan kuesioner Moca-Ina versi Indonesia untuk menilai fungsi kognitif dan Indeks Barthel untuk menilai tingkat kemandirian. Untuk menilai keadaan sosiodemografi dinilai melalui wawancara. Hasil penelitian ini didapatkan hasil hubungan tingkat kemandirian dan gangguan kognitif pada lansia dengan hasil $p=0.209$. Untuk hasil tingkat kemandirian didapatkan hasil tingkat mandiri (92\%), fungsi kognitif umumnya berada pada mild kognitif (76\%). Dari penelitan ini disimpulkan hubungan tidak bermakna tingkat kemandirian dengan gangguan kognitif.
\end{abstract}

Keywords: lansia, tingkat kemandirian, gangguan kognitif

\begin{abstract}
Increasing the number of elderly population is a challenge for fulfillment of facilities, systems and roles of government and society with the aim of improving the quality of life of the elderly. One aspect related to the aging process is a decline in functions that include psychological, sociological and biological. One change is a decline in cognitive function. Declining function in the elderly is also a factor influencing the level of independence of the elderly. The purpose of this study was to assess the relationship between the level of independence and cognitive impairment in the elderly. This study used a cross-sectional design with convenience-sampling techniques. Data collection used the Moca-Ina questionnaire to assess cognitive function and the Barthel Index to assess the level of independence. Assessing of sociodemography assessed through interviews. The results of this study found the relationship between the level of independence and cognitive impairment in the elderly with the results of $p=0.209$. The results of the level of independence obtained by the level of independence (92\%), cognitive function is generally in mild cognitive (76\%). From this research, it was concluded that there was no significant relationship between the level of independence and cognitive impairment.
\end{abstract}

Keywords: elderly, level of independence, cognitive impairment 


\section{PENDAHULUAN}

Penduduk usia lanjut (lansia) di Indonesia cenderung meningkat. Indonesia berkontribusi signifikan dalam pertumbuhan lansia secara global. Peningkatan populasi lansia menjadi sebuah tantangan. Tantangan pada pertumbuhan dan perkembangan daerah tertinggal, peningkatan pelayanan dan fasilitas puskesmas, optimalisasi jaminan kesehatan dan berbagai program lainnya. ${ }^{1}$

Beberapa kota juga memberikan pelayanan sarana dan prasarana kota yang ramah pada lansia. Tujuan dari jawaban tantangan tersebut adalah peningkatan kualitas hidup lansia. ${ }^{1}$

Tantangan lain pada status kesehatan lansia. Penurunan fungsi pada lansia mencakup perubahan psikologis, sosiologis dan biologis. Perubahan psikologis dapat diakibatkan oleh perubahan dari yang dulunya bekerja, kemudian tidak bekerja, kesepian, dan risiko penyakit yang diderita. Perubahan sosiologis dipengaruhi oleh tingkat pendidikan, yang memberikan penilaian terhadap pemahaman diri sendiri. ${ }^{1,2}$

Perubahan biologis terdiri dari penurunan fungsi sel, kemampuan motorik, massa otot, penurunan penglihatan dan indra pendengaran. ${ }^{2,3}$ Penurunan fungsi kognitif menjadi salah satu masalah kesehatan yang sering muncul pada lansia. ${ }^{3}$

Penurunan fungsi kognitif dapat dinilai menggunakan tes Montreal Cognitive Assessment versi Indonesia (MoCA Ina), tes ini lebih sensitive dibandingkan tes MMSE. ${ }^{3}$ Total skor dari tes ini adalah 30 poin. Penilaian meliputi fungsi eksekutif, visuospasial, Bahasa, delayed recall, atensi, abstraksi, dan orientasi. ${ }^{3-9}$

Demensia sebagai salah satu gangguan kognitif merupakan penyebab utama ketergantungan lansia pada anggota keluarga. ${ }^{5}$ Kualitas hidup lansia, dinilai dengan kemandirian seorang lansia, dan kemampuan lansia menikmati masa tuanya. ${ }^{10}$ Lansia dengan demensia menyebabkan ketergantungan pada keluarga. Seperti yang disampaikan BPS tahun 2018, ketergantungan lansia meningkat kepada penduduk produktif. ${ }^{1}$

Kualitas hidup pada dasarnya merupakan perasaan subjektif dari seseorang, sehingga tidak dapat didefinisikan secara pasti. Akan tetapi, diasosiasikan dengan kehidupan yang baik, kepuasaan terhadap kehidupan, termasuk dari aspek kemandirian. ${ }^{7}$

Kualitas hidup lansia dan segala perubahannya tidaklah dapat dihindari, sehingga untuk meperthankan kualitas hidup perlu mekanisme adaptasi seorang lansia dengan proses penuaan. ${ }^{5,11-13}$

Kemandirian lansia juga perlu diperhatikan, penyakit degeneratif yang bisa diderita oleh lansia dapat menjadi penyebab ketergantungan lansia. Tujuan dari penelitian ini adalah untuk melihat hubungan tingkat kemandirian dengan gangguan kognitif pada lansia.

\section{METODE PENELITIAN}

Penelitian ini menggunakan pendekatan desain cross sectional. Ruang lingkup penelitian ini merupakan bagian neurologi dan kejiwaan Populasi penelitian merupakan lansia yang berada yang merupakan pasien Prolanis (Program Pengelolaan Penyakit kronis) yang berusia 60-80.

Peserta Prolanis merupakan pasien dengan penyakit kronis. Pendekatan pengambilan sampel pada penelitian ini menggunakan non-probability sampling dengan teknik convenience sampling. Besar sampel penelitian yang memenuhi kriteria sampling adalah 25 orang lansia. 
Dalam penelitian ini juga dicatat mengenai karakteristik dasar sosiodemografi yang meliputi jenis kelamin (laki-laki dan perempuan), usia (kelompok lansia muda dan lansia madya), tingkat pendidikan (Tidak lulus SD, SD, SMP, SMA, dan sarjana), dan status marital (menikah, masih memiliki pasangan hidup, duda/janda).

Kriteria inklusi pada penelitian ini adalah lansia yang dapat membaca dengan atau tanpa kecamata, dan tidak mengalami gangguan berkomunikasi. Variabel yang dideskripsikan adalah karakteristik lansia berupa jenis kelamin, usia dan status marital, kemandirian lansia dan fungsi kognitif lansia.

Cara penilaian mengunakan Montreal Cognitive Assessment (MoCA) yang berasal dari kanada, yang versi Indonesia (MoCAIna). Penilaian menggunakan MoCA-Ina telah banyak digunakan untuk menilai fungsi kognitif. ${ }^{3}$ Untuk menilai variable kemandirian menggunakan penilaian Activity daily Living Barthel (ADL Barthel) versi Indonesia. ${ }^{11}$

Data dinalisis menggunakan SPSS 25.0. Analisis univariat ditampilkan dengan table distribusi frekuensi, yati data karakeristik, Kemandirian dan fungsi kognitif. Analisis bivariat menggunakan uji Spearman.

\section{HASIL DAN PEMBAHASAN}

Karakteristik lansia yang dilakukan pendataan sosiodemografi.

Tabel 1. Karakteristik Responden

\begin{tabular}{lcc}
\hline Karakteristik & f & \% \\
\hline Jenis Kelamin & & \\
$\quad$ Laki-laki & 7 & 28 \\
$\quad$ Perempuan & 18 & 72 \\
Usia & & \\
$\quad$ Lansia muda (60-69) & 15 & 60 \\
$\quad$ Lansia madya (70-79) & 10 & 40 \\
Status marital & &
\end{tabular}

$\begin{array}{lll}\text { Menikah } & 17 & 68\end{array}$

Duda/janda $\quad 8 \quad 32$

Tingkat pendidikan

Tidak lulus SD $\quad 5 \quad 20$

$\begin{array}{lll}\text { SD } & 8 & 32\end{array}$

$\begin{array}{lll}\text { SMP } & 2 & 8\end{array}$

$\begin{array}{lll}\text { SMA } & 7 & 28\end{array}$

Sarjana $\quad 3 \quad 12$

Dari data di atas, lebih banyak responden berjenis kelamin perempuan, status pernikahan responden menikah, untuk usia lebih banyak yang lansia muda dengan rentang usia 60-69 tahun, untuk sebaran tingkat pendidikan bervariasi mulai dari tidak lulus SD sampai sarjana.

Berdasarkan tingkat kemandirian yang dinilai dengan ADL Barthel versi Indonesia, dikategorikan menjadi mandiri dan ketergantungan ringan.

Tabel 2. Tingkat Kemandirian Lansia

\begin{tabular}{lcc}
\hline Tingkat Kemandirian & f & \% \\
\hline Mandiri & 23 & 92 \\
Ketergantungan ringan & 2 & 8 \\
\hline
\end{tabular}

Penilaian tingkat kemandirian menggunakan penilaian ADLBarthel Indeks. Responden umunya mandiri, terdapat 2 orang responden yang ketergantungan ringan, dan latar belakang responden ini adalah dengan penyakit post stroke dalam 6 bulan terakhir.

Tabel di atas menunjukkan lasia muda dan madya berada pada tingkat kemandirian. Penyakit penyerta yang juga menyertai proses penuaan menjadi salah satu faktor penoyebab ketergantungan lansia.

Perubahan kognitif yang juga dialami lansia dinilai menggunakan kuesioner MocaIna. Dari kuesioner ini didapatkan kategori fungsi kognitif normal, mild kognitif dan demensia.

Tabel 3. Tabel Fungsi Kognitif 


\begin{tabular}{lll}
\hline Fungsi kognitif & F & \% \\
\hline Normal & 2 & 8 \\
Mild kognitif & 19 & 76 \\
Demensia & 4 & 16 \\
\hline
\end{tabular}

Dari table di atas dapat disimpulkan $76 \%$ lansia mengalami mild kognitif. Pertambahan usia, pada sel saraf juga mengalami kematian, sedangkan sel saraf manusia tidak dapat melakukan mitosis, sehingga sel tidak dapat berregerasi mejadi sel baru. Dengan adanya sel yang mati, artinya jumlah sel menjadi berkurang sehingga terjadi atrofi jaringan saraf. ${ }^{5,6,8}$

Selain usia, faktor yang memepengaruhi penurunan fungsi kognitif yaitu tingkat pendidikan, riwayat trauma kepala, peyakit vascular dan penyakit komorbid lainnya., Pada umumnya lansia memiliki gangguan dalam pemprosesan memori jangkan pendek. Hal ini disebabkan menurunnya fungsi dalam menangkap dan menimpan informasi secara efektif. ${ }^{8}$

Berdasarkan penelitian sebalumnya, gangguna kognitif sebagai salah satu faktor yang mempengaruhi kemandirian dari lansia. Penilaian hubungan dari dua variable yaitu fungsi kognitif dan tingkat kemandirian lansia dengan menggunakan uji Spearman rho.

Tabel 4. Hubungan tingkat kemandirian dan fungsi kognitif

\begin{tabular}{lcc}
\hline & \multicolumn{2}{c}{ Fungsi Kognitif } \\
\cline { 2 - 3 } & $\mathrm{p}$ & $\mathrm{r}$ \\
\hline Tingkat & 0.209 & 0.260 \\
kemandirian & & \\
\hline
\end{tabular}

Dari table di atas dapat disimpulkan bahwa pada penelitian ini tidak didapatkan hubungan bermakna antara tingkat kemandirian dengan fungsi kognitif. Hal ini bisa disebabkan oleh jumlah sampel yang sedikit.
Berdasarkan penelitian sebelumnya tingkat kemandirian dipengaruhi oleh gangguan kognitif. Pada penelitian ini yang mengalami gangguan kognitif 4 orang, sedangkan lansia lain yang menjadi responden normal dan gangguan ringan kognitif.

\section{SIMPULAN}

Pada penelitian ini tidak didapatkan hubungan bermakna tingkat kemandirian dan gangguna kognitif. Hal ini dapat disebabkan oleh jumlah sampel yang sedikit yang menajadi keterbatasan dalam penelitian ini. Tingkat kemandirian tidak hanya dipengaruhi oleh satu faktor akan tetapi multifactorial. Untuk penelitian selanjutnya dapat dinilai faktor-faktor yang memepengaruhi tingkat kemandirian pada lansia.

\section{UCAPAN TERIMAKASIH}

\section{REFERENSI}

1. Dwi Susilo, Ida Eridawaty Harahap RS. Statistik Penduduk Lanjut Usia 2018.

2. Sari DMP, Lestari CYD, Putra EC, Nashori F. Kualitas Hidup Lansia Ditinjau Dari Sabar Dan Dukungan Sosial. J Ilm Psikol Terap. 2018;6(2):131.

doi:10.22219/jipt.v6i2.5341

3. Rasyid IA, Syafrita Y, Sastri S. Hubungan faktor resiko dengan fungsi kognitif pada lanjut usia kecamatan padang panjang timur kota padang panjang. Hub Fakt resiko dengan fungsi Kogn pada lanjut usia Kec padang panjang timur kota padang panjang. 2017;6(1):49-54.

4. Coresa T, Ngestiningsih D. Gambaran Fungsi Kognitif Pada Lansia Di Unit. $J$ Kedokt Diponegoro. 2017;6(1):114-119.

5. Epidemiologi B, Masyarakat FK. 
Gambaran Gangguan Kognitif Dan Fungsional (Iadl)Padalansia Di Kelurahan Kramas,Kecamatan Tembalang, Kota Semarang. J Kesehat Masy. 2019;7(1):168-175.

6. Harry Sundariyati IGA, Ratep N, Westa W. Gambaran faktor-faktor yang mempengaruhi status kognitif pada lansia di wilayah kerja puskesmas kubu II, Januari-Februari 2014. E-Jurnal Med Udayana; vol 4 no 1 (2015)e-jurnal Med udayana. 2015. https://ojs.unud.ac.id/index.php/eum/artic le/view/12634.

7. Wikananda G. Hubungan Kualitas Hidup dan Faktor Resiko pada Usia Lanjut di Wilayah Kerja Puskesmas Tampaksiring 1 Kabupaten Gianyar Bali 2015. Intisari Sains Medis. 2017;8(1):1-12. doi:10.15562/ism.v8i1.112

8. Djajasaputra ADR, Halim MS. Fungsi Kognitif Lansia yang Beraktivitas Kognitif secara Rutin dan Tidak Rutin. $J$ Psikol. 2019;46(2):85. doi:10.22146/jpsi.33192

9. Andesty D, Syahrul F, Epidemiologi D, Masyarakat FK, Airlangga U. Hubungan Interaksi Sosial Dengan Kualitas Hidup Lansia Di Unit Pelayanan Terpadu ( Uptd ) Griya Werdha Kota Surabaya Tahun 2017 Pendahuluan .Indones J Public Heal. $\quad$ 2018;13(December):169-180. doi:10.20473/ijph.vl13il.2018.169-180

10. Nur Rohmah AI. Kualitas Hidup Lanjut Usia. J Keperawatan. 2012;3(2):120-132.

11. Tornero-Quiñones I, Sáez-Padilla J, Díaz AE, Robles MTA, Robles ÁS. Functional ability, frailty and risk of falls in the elderly: Relations with autonomy in daily living. Int J Environ Res Public Health. 2020;17(3):1-12.

doi:10.3390/ijerph17031006

12. Indrayani SR. Faktor-Faktor Yang Berhubungan Dengan Kualitas Hidup Lansia Di Desa Cipasung Kabupaten
Kuningan. $J$ Kesehat reproduksi. 2018;9(1):69-78. doi:10.22435/kespro.v9i1.892.69-78

13. Putri ST, Fitriana LA, Ningrum A. Studi Komparatif: Kualitas Hidup Lansia Yang Tinggal Bersama Keluarga Dan Panti. J Pendidik Keperawatan Indones. 2015;1(1):1. doi:10.17509/jpki.v1i1.1178 